\title{
NUMERICAL STUDY ON SHEAR BEHAVIOR OF REINFORCED CONCRETE SIMPLE BEAMS WITH DIFFERENT SHEAR-SPAN RATIOS
}

\author{
異なるせん断スパン比を持つ鉄筋コンクリート単純梁のせん断挙動 \\ に関する数值解析的研究
}

\author{
Yoshio KANEKO* and Hirozo MIHASHI ** \\ 金子佳生, 三橋博三
}

\begin{abstract}
The objective of this paper is to examine the performance of constitutive models for describing the cracking behavior and the loaddisplacement characteristics of shear failure of concrete structures. Concrete simple deep beams in different shear-span ratios (0.5 to 2.0) were analyzed. In addition, in order to expand the comprehension on the effect of constitutive model parameters in the deep beams to slender beams, the beams in the shear-span ratio of 4.0 were numerically simulated. The structural analysis was carried out by means of nonlinear finite element method. A smeared crack approach using rotating crack model without shear strain on the crack plane was employed. Based on this analytical work, the effect of the compressive strength reduction after cracking and the post-peak ductility in the constitutive law on shear fracture behavior for different shear-span ratios was discussed.
\end{abstract}

Keywords: Shear failure of concrete structures, Shear-span ratio, Nonlinear FEM analysis, Strength reduction after cracking, Post-peak ductility コンクリート構造のせん断破壊、せん断スパン比、非線形有限要素法解析、ひび割れ後の強度低下、ポストピーク勒性

\section{INTRODUCTION}

The mechanism of shear fracture in concrete structures has been the subject of heated debates in past decades. Yet, it has not been sufficiently clarified. On the other hand, several crack approaches as well as constitutive models for concrete under both uniaxial tension and compression loading have been proposed in many researches ${ }^{1)}$. However, reliable predictions for the extreme complex shear failure in concrete structures have not been achieved. The complexity of the shear failure depends considerably on how much the failure mode is governed by crushing behavior.

There are two representative numerical approaches to implement a crack model based on the Fracture Mechanics: discrete crack approach and smeared crack approach ${ }^{2)}$. The discrete crack approach is a direct application of crack models. Crack growth is analyzed on the assumption that cohesive forces are acting in the process zone. The complexity of the finite element analysis depends very much on whether the crack path is assumed in advance or not. If the crack path is not known in advance, the problem is much complicated. In the smeared crack approach, a cracked solid is assumed to be a continuum with the notion of stress and strain ${ }^{3}$. The behavior of cracked concrete can then be described in terms of stress- strain relations and it is sufficient to switch from the initial isotropic stressstrain relation to an orthotropic stress-strain relation upon cracking. As a consequence, the topology of the original finite element mesh remains preserved which is computationally convenient. The two approaches presently seem to achieve better performance in different types of applications. In general, the smeared approach is better suited for engineering analyses of distributed fracture, while the discrete approach has its strength in detailed analyses of localized fracture. Thus, the smeared crack approach may be employed for a rough estimation of the loaddisplacement relation of shear failure of concrete structures in the practical design.

In this paper, the performance of constitutive models for describing the cracking behavior and the load-displacement characteristics of shear failure of concrete structures was examined. The problem on shear failure of RC beams in different shear-span ratios was employed as a practical application of the numerical modeling. The shear failure mode of RC beams changes complexly according to the shear span-ratio. Specifically, the shear failure mode of RC beams in relatively small shear span-ratio is governed by the interaction between the cracking behavior and the crushing behavior, while
* Assoc. Prof., Tohoku University, Graduate School of Engineering, Ph. D.

** Prof., Tohoku University, Graduate School of Engineering, Dr. Eng.
東北大学大学院工学研究科 助教授 $\cdot$ Ph. D.

東北大学大学院工学研究科 教授. 工博 
the shear failure mode of $\mathrm{RC}$ beams in relatively large shear span-ratio is mainly governed by the cracking behavior. The intent of the present analysis is to investigate the practical approach to achieve the reliable prediction of the complex phenomena. In addition, the clarification on the performance of constitutive models for the complex failure could be useful in the material research.

The numerical simulations were carried out in the two-step procedure. Firstly, the appropriate parameters are determined in both compressive and tensile constitutive models so as to approximate the peak load and loaddisplacement relation obtained in the experiments, and to describe the cracking behavior observed in the experiments. This analysis is considered as the benchmark analysis. Thereafter, the sensitivity of the numerical results to the compression and tension softening parameters is examined. This analysis is considered as the parametric analysis. Based on this analytical work, the performance of the constitutive model parameters for different shear-span ratios was addressed.

\section{BENCHMARK ANALYSIS}

\subsection{Review of Experiments}

The simple deep beam tests were numerically simulated in practice. The experimental work was conducted by Niwa ${ }^{4)}$ to confirm the shear strength and formulate the design method of deep beams. The specimen and loading system for the test are shown in Fig. 1. Roller supports were provided at both the supporting and the loading points. The yield strength of main steel bar and transverse web reinforcement is $375.3 \mathrm{MPa}$ and 400.8 $\mathrm{MPa}$, respectively. The details of specimens, the material properties and the failure modes in the test are shown in Table 1. For the concrete, a water-cement ratio of $44 \%$ and the maximum aggregate size of $10 \mathrm{~mm}$ were adopted.

The shear tests were carried out in a displacement-control-testing machine. The vertical relative displacement measured between the loading point and the supporting point was considered as the shear displacement. The observed failure modes in all tests are classified in Table 1. DC stands for the shear failure accompanied with obvious crushing at the web concrete, and SL stands for the shear failure without

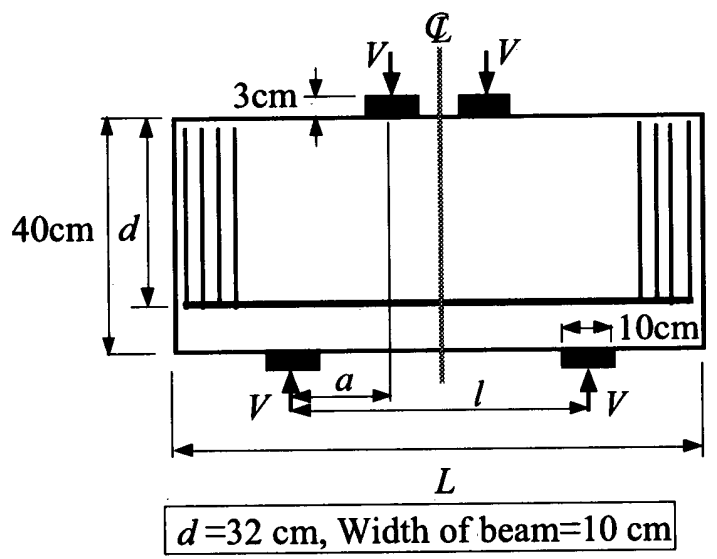

FIG. 1: Specimen and Loading System obvious crushing at the web concrete. In the case of the shear-span ratio a/d lower than or equal to 1.0 , a diagonal crack initiated at the web concrete and the shear load further increased. At the load level close to the peak, another crack propagated downward from the bottom edge of upper bearing plate and the concrete between cracks was crushed, finally leading to a slipoff along the connected cracks. In the case of $a / d$ higher than or equal to 1.5 , the shear load further increased after the initiation of a diagonal crack. The diagonal crack propagated upward without obvious crushing at the web concrete, and thrust against the bottom edge of upper bearing plate, finally leading to a brittle failure.

TABLE 1: Detail of Specimens, Material Properties and Failure Modes

\begin{tabular}{|c|c|c|c|c|c|c|c|c|}
\hline & $\begin{array}{c}a \\
(\mathrm{~cm})\end{array}$ & $a / d$ & $\begin{array}{c}l \\
(\mathrm{~cm})\end{array}$ & $\begin{array}{c}L \\
(\mathrm{~cm})\end{array}$ & $\begin{array}{c}p_{w} \\
(\%)\end{array}$ & $\begin{array}{c}p_{r} \\
(\%)\end{array}$ & $\begin{array}{c}f_{c} \\
(\mathrm{MPa})\end{array}$ & Failure Mode \\
\hline S1 & 16.0 & 0.5 & 46.0 & 90.0 & 3.72 & 4.46 & 53.74 & DC \\
\hline S2 & 32.0 & 1.0 & 78.0 & 120.0 & 3.72 & 1.33 & 53.74 & DC \\
\hline S3 & 48.0 & 1.5 & 110.0 & 150.0 & 3.72 & 0.59 & 53.74 & SL \\
\hline S4 & 64.0 & 2.0 & 142.0 & 180.0 & 3.72 & 0.45 & 53.74 & SL \\
\hline
\end{tabular}

$p_{w}$ : ratio of main steel bar; $p_{r}$ : ratio of transverse web reinforcement

$f_{c}^{\prime}$ : compressive strength of concrete

\subsection{Finite Element Analysis}

The structural analysis was carried out using SBETA ${ }^{5)}$ Finite Element Program developed by V. Cervenka et al. A smeared crack approach using a rotating crack model was employed. In addition, the following effects of concrete behavior were considered: nonlinear behavior in compression including hardening and softening; fracture of concrete in tension based on nonlinear fracture mechanics; biaxial stress failure criterion ${ }^{6)}$ by means of equivalent uniaxial stress-strain relationship ${ }^{7}$; reduction of compressive strength after cracking ${ }^{8)}$. The details of the numerical formulation are given in SBETA ${ }^{5}$.

The present study focuses mainly on the softening parameters of the constitutive models. Regarding the compressive constitutive models, the reduction of the compressive strength after cracking in the direction parallel to the cracks was applied, and several strength reduction rates were considered. A linearly descending softening law in compression was adopted and the influence of the end-point of the softening curve on the predicted load-displacement relations was also examined. Regarding the tensile constitutive models, an exponential crack opening model, a linear crack opening model and a tension cut-off model were alternatively employed. In the rotating crack model ${ }^{9)}{ }^{10}$, the direction of the principal stress coincides with the direction of the principal strain. No shear strain occurs on the crack plane and only two normal stress components must be defined. If the principal strain axes rotate during loading, the direction of cracks also rotates.

Behavior of concrete in tension without crack was assumed linearly elastic. After cracking, three types of models were alternatively used in this analysis for the crack opening as shown in Fig. 2. The function of the exponential crack opening model was empirically derived by Hordijk ${ }^{11)}$ as follows: 


$$
\begin{aligned}
& \frac{\sigma_{t}}{f_{t}^{e f}}=\left\{1+\left(c_{1} \frac{w_{t}}{w_{t}^{c r}}\right)^{3}\right\} e^{\left(-c_{2} \frac{w_{t}}{w_{t}^{c r}}\right)}-\frac{w_{t}}{w_{t}^{c r}}\left(1+c_{1}^{3}\right) e^{\left(-c_{2}\right)} \\
& w_{t}^{c r}=5.14 \frac{G_{F}}{f_{t}^{e f}}
\end{aligned}
$$

where $w_{t}$ is the crack opening displacement, $w_{t}^{\sigma r}$ is the crack opening displacement at the complete release of stress, $\sigma_{t}$ is the normal stress in the crack and $f_{t}^{e f}$ is the effective tensile strength associated with the biaxial stress failure criterion according to Kupfer ${ }^{6}$ ). Values of the constants are $c_{I}=3.0$ and $c_{2}=6.93 . \quad G_{F}$ is the fracture energy needed to create a unit area of stress-free crack. The crack opening displacement $w_{t}$ is derived from

(a)

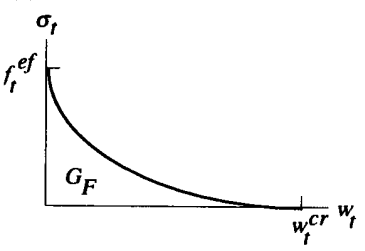

(b)

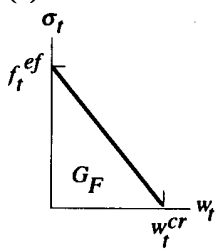

(c)

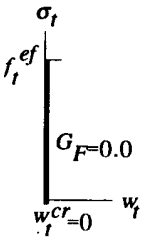

FIG. 2: (a) Exponential Crack Opening Model; (b) Linear Crack Opening Model; (c) Tension Cut-off Model

(a)

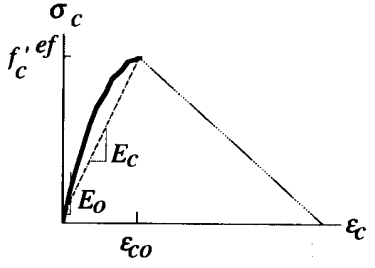

FIG. 3: Constitutive Model in Compression for (a) Ascending Branch; (b) Descending Branch

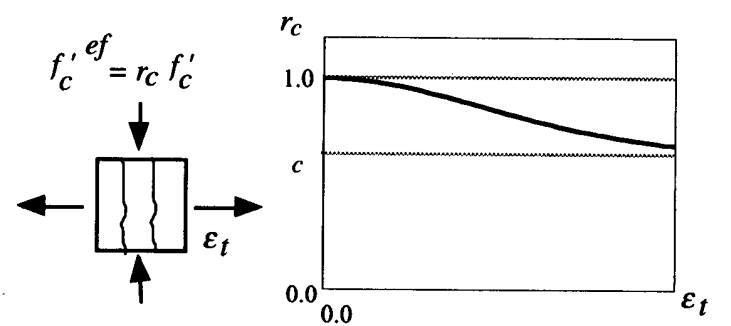

FIG. 4: Reduction of the compressive strength after cracking strains based on the Crack Band Theory. The linear crack opening model gives the relation of $w_{t}^{c}=2 G_{F} / f_{t}^{e f}$ and the tension cut-off model has no softening regime and abrupt stress-drop after cracking.

For the ascending branch of concrete stress-strain curve in compression, the formula recommended by CEB-FIP Model Code $90^{12)}$ was adopted (see Fig. 3a).

$$
\sigma_{c}=f_{c}^{\prime e f} \frac{k x-x^{2}}{1+(k-2) x}, \quad x=\frac{\varepsilon_{c}}{\varepsilon_{c 0}}, \quad k=\frac{E_{0}}{E_{c}}
$$

where $\varepsilon_{c}$ is the compressive strain, $\sigma_{c}$ is the compressive stress, $f_{c}^{\prime}{ }^{e f}$ is the effective compressive strength associated with the biaxial stress failure criterion according to Kupfer ${ }^{6}$, $\varepsilon_{c 0}$ is the strain at the peak stress, $k$ is a shape parameter and the value of 2.0 was used in this analysis for parabola, $E_{o}$ is the initial elastic modulus, $E_{c}$ is the secant elastic modulus at the peak stress.

For the descending branch of concrete constitutive curve in compression, a fictitious compression plane model is used in SBETA based on the assumption that a compression failure is localized in a plane normal to the direction of compressive principal stress. All post-peak compressive displacements and energy dissipation are localized in this plane. It is assumed that the displacements are independent of the size of the structure and such hypothesis is supported by experiments conducted by van Mier ${ }^{13)}$. Softening law in compression is linearly descending. The end point of the softening curve is defined as a limit displacement $w_{c}^{c r}$ at the complete release of stress (see Fig. 3b).

The reduction of the compressive strength after cracking in the direction parallel to the cracks is considered in a similar way as found in the experiments of Vecchio and Collins ${ }^{9)}$. The reduction function was empirically developed by Kolleger et al. ${ }^{8)}$ as follows:

$$
f_{c}^{\prime e f}=r_{c} f_{c}^{\prime}, \quad r_{c}=c+(1-c) e^{-\left(128 \varepsilon_{t}\right)^{2}}
$$

where $r_{c}$ is the compressive strength reduction rate, $\varepsilon_{f}$ is the transverse strain (crack opening strain) and $f_{c}^{\prime}$ is the concrete compressive strength. For zero transverse strain, there is no strength reduction and for large strains the strength asymptotically approaches the minimum value $f_{c}^{\prime e f}=c f_{c}^{\prime}$ (see Fig. 4). The constant $c$ is the maximum strength reduction rate under a large transverse strain.

In the constitutive models, the initial elastic modulus $E_{0}$ and the tensile strength $f_{l}$ of concrete are estimated using the following equations ${ }^{14), 15)}$ :

$$
\begin{aligned}
E_{0}=4733 \sqrt{f_{c}^{\prime}} & (M P a) \\
f_{t}=0.332 \sqrt{f_{c}^{\prime}} & (M P a)
\end{aligned}
$$

The fracture energy $G_{F}$ was assumed as $0.1 \mathrm{~N} / \mathrm{mm}$ except the tension 
cut-off model $\left(G_{F}=0.0\right)$, a value often used by many researchers ${ }^{3)}$. In addition, Balakrishnan and Murray ${ }^{16)}$ suggested values between 0.05 $\mathrm{N} / \mathrm{mm}$ and $0.25 \mathrm{~N} / \mathrm{mm}$, with $0.1 \mathrm{~N} / \mathrm{mm}$ being the most effective.

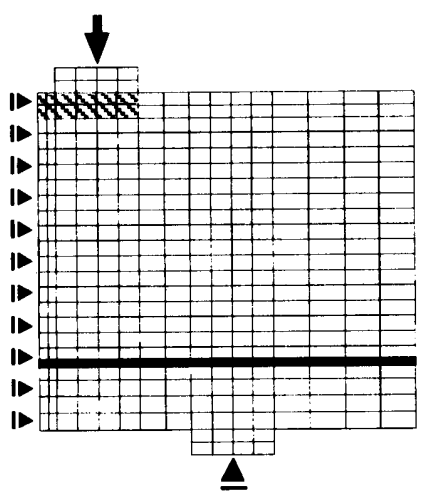

FIG. 5: Configuration of FEM Model for S1 Beam

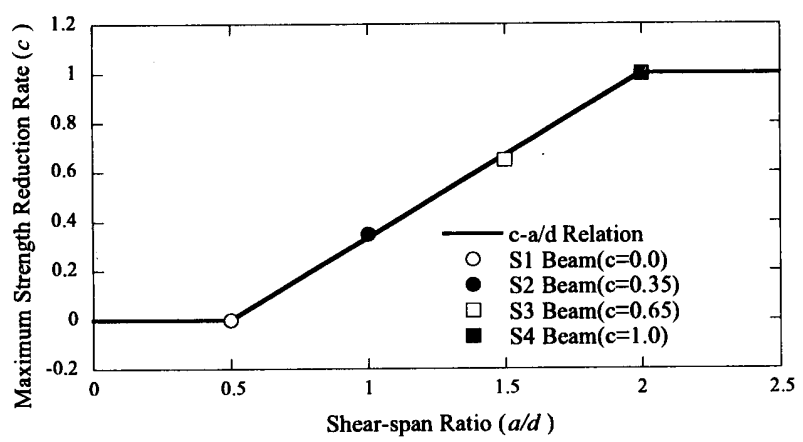

FIG. 6: Maximum Compressive Strength Reduction Rate (c) vs. Shear-span Ratio Curve in Benchmark Analysis

(a)

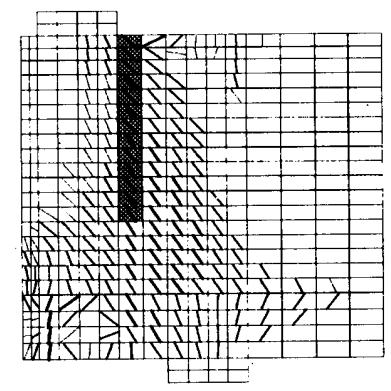

(b)

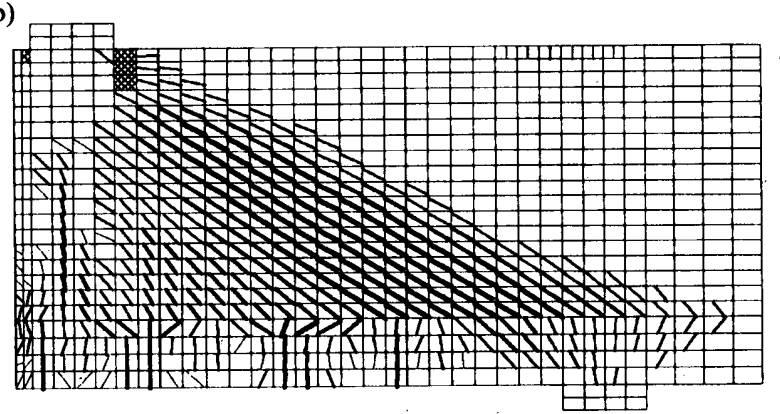

FIG. 7: (a) Cracking Patterns at Peak Load for S1 Beam; (b) Cracking Patterns at Peak Load for S4 Beam

\subsection{Comparison between Experiments and Benchmark Analysis}

The FEM model employed here was chosen to describe the test configuration of Niwa ${ }^{4)}$. After some trials in preliminary numerical studies, the geometric and loading configuration as well as mesh profile were adopted in the FEM model. The configuration of the FEM model for S1 beam (see Table 1) is shown in Fig.5. Considering the symmetry of the specimen, only half of the structure is analyzed. It should be noted that the strength of the hatched elements in the figure is increased in $80 \%$ to consider three dimensional compression state due to the restraint of the bearing plates based on the numerical study by Niwa ${ }^{4)}$. The specimen is assumed to be in a state of plane stress. Finite plane stress elements consist of quadrilaterals composed of two four-node sub-triangles. The stress-strain relation in reinforcement is assumed as a perfectly elastoplasticity. The main steel bar (thick line) at the bottom of the beam is modeled by a discrete bar finite element which is embedded and passing through quadrilateral elements as shown in Fig. 5. The bar element has only axial stiffness and is in the uniaxial stress-state. It should be noted that on a macro-level, a relative slip distance of reinforcement with respect to concrete over a certain distance arise, if concrete is cracked or crushed. The transverse web reinforcement is modeled by a smeared reinforcement which stress and stiffness are considered in the quadrilateral element. While the vertical displacement of the support of the specimen is restrained, a vertical prescribed displacement is applied at the loading point.

In the benchmark analysis, an exponential crack opening model is used (see Fig. 2a). The adopted quantities of the maximum strength reduction rate $c$ are shown in Fig. 6, and the adopted limit displacement $w_{c}{ }_{c}^{c r}$ is 1.0 $\mathrm{mm}$ (see Fig. 3b). Particularly to approximate the peak load, $c=0.0$ was assumed for $a / d=0.5$ or lower, and no strength reduction $(c=1.0)$ for $a / d=2.0$ or higher. In the case of the shear-span ratios between 0.5 and 2.0, the interpolating values of $c$ between 0.0 and 1.0 are adopted, as shown in Fig. 6. Here, it should be noted that the relation between $c$ and shear span-ratio in the figure is consistent with the experimental observation such that the smaller is the shear span-ratio, the stronger is the interaction between cracking and crushing. However, to formulate the constitutive model on the shear span-ratio, further experimental and numerical study is necessary.

First, the cracking behavior predicted by the FEM analysis is examined. The cracking patterns at the peak load for S1 and S4 beams are shown in Figs. $7 \mathrm{a}$ and $7 \mathrm{~b}$. In the figures, the hatched area indicates the crushed concrete and the thicker crack line indicates the larger crack width. In the shear-span ratio of $a / d=1.0$ or lower, the shear failure accompanied with heavy crushing at the web concrete was observed. Flexural cracks initiate at the bottom of the beam and subsequently diagonal cracks initiate at the web concrete. At the load level close to the peak, the crushed concrete zone associated with widely opened diagonal cracks at the bottom edge of upper bearing plate grows downward, leading to a slip-off failure. In the shear-span ratio of $a / d=1.5$ or higher, the shear failure without obvious crushing at the web concrete is observed. Flexural cracks initiate at the bottom of the beam and propagate to the mid-depth of the beam. Subsequently, diagonal cracks initiate at the web concrete and continue to propagate along the line between the loading point and the support, and 
grow excessively wide. Nearly at the peak load level, the compression failure is observed at the extreme compression fiber, and the diagonal cracks thrust against the bottom edge of upper bearing plate, leading to a brittle failure. In the shear-span ratio of $a / d=0.5$, no yield of reinforcement is observed. However, in the shear-span ratio of $a / d=1.0$ or higher, the transverse reinforcement is partially yielded. Based on the comparisons of cracking behavior between the FEM analysis and the experiment, it may be concluded that the FEM model in the benchmark analysis approximates the cracking behavior and the failure mode of test results.

Fig.8a shows the comparison between the results of shear loaddisplacement relations obtained in the experiment and in the FEM analysis. The numerical simulation approximates the overall test results. A more precise prediction may be obtained with modified parameters of constitutive models as well as modified geometric configuration and mesh profile. However, the current results already show that both the cracking behavior and the load-displacement characteristics were captured overall by the adopted FEM model. Therefore, the current FEM model can be used as the benchmark analysis to examine the effect of constitutive model parameters for shear failure of concrete beams, discussed next.

\section{PARAMETRIC ANALYSIS ON CONSTITUTIVE PARAMETERS}

\subsection{Influence of Softening Parameters in Compression}

The sensitivity of the results from the numerical simulation to each of the maximum strength reduction rate $c$ and the limit displacement $w_{c}{ }^{c r}$ was examined. Fig. $8 \mathrm{~b}$ shows the comparison between the results of shear load-displacement relations in the benchmark analysis and in the parametric analysis with the maximum strength reduction rate $c$ of 0.0 or 1.0. In this parametric analysis, the tensile constitutive model and the value of the limit displacement $w_{c}^{c r}$ are identical to that in the benchmark analysis. The difference between the predicted load-displacement curves with $c=0.0$ and $c=1.0$ is considerably large in the case of $a / d=0.5$. The difference is however reduced in the larger shear-span ratio. The predicted failure mode with $c=1.0$ for $\mathrm{S} 1$ beam is different from that observed in the benchmark analysis as shown in Fig. 7a. The peak load is associated with the bearing compression failure just above the lower bearing plate, instead of the crushing of compression strut at the web concrete. It may be explained by the fact that the condition of no compressive strength reduction after cracking $(c=1.0)$ gives a large crushing resistance to the compression strut at the web concrete, resulting in the further increase of the shear load, and allowing the bearing compression failure. The larger is the value of $c$, the higher is the crushing resistance of the compression strut at the web concrete. The condition of $c=0.0$ gives crushing behavior at the web concrete for S3 and S4 beams, which was not observed in both the experiment and the benchmark analysis. Thus, the predicted failure modes and load-displacement curves are strongly influenced by the value of $c$.

Fig. 8c shows the comparison between the results of shear loaddisplacement relations in the benchmark analysis and in the parametric analysis with the limit displacement $w_{c}^{c r}$ of $0.5 \mathrm{~mm}$. In this parametric analysis, the tensile constitutive model and the value of the maximum strength reduction rate $c$ are identical to those in the benchmark analysis. There is no obvious difference of the predicted failure modes between the parametric analysis and the benchmark analysis with respect to cracking behavior. The limit displacement $w_{c}^{c r}$ considerably influences the entire load-displacement relation as well as the peak load in the case of $a / d=1.0$ or higher. The larger is the limit displacement, the higher is the peak load. However, in the case of $a / d=0.5$, this parameter does not influence the entire load-displacement relation and neither the peak load. It may be (a)

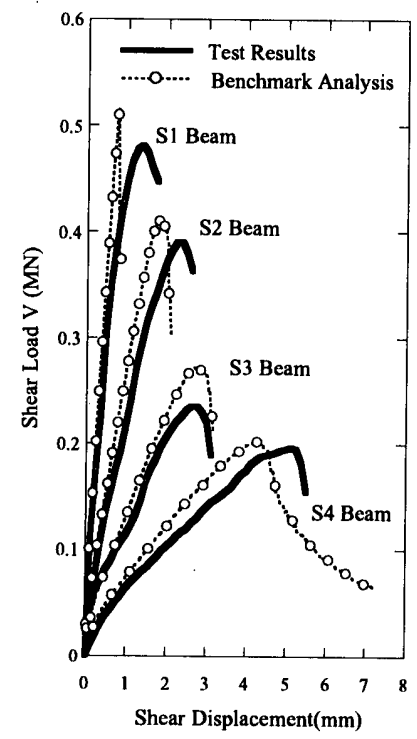

(b)

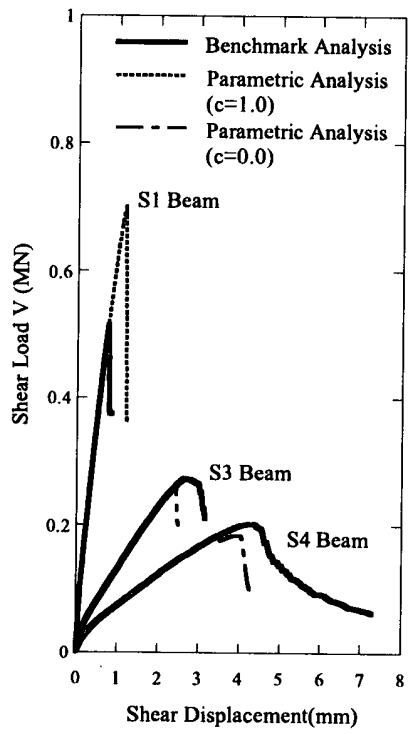

(c)

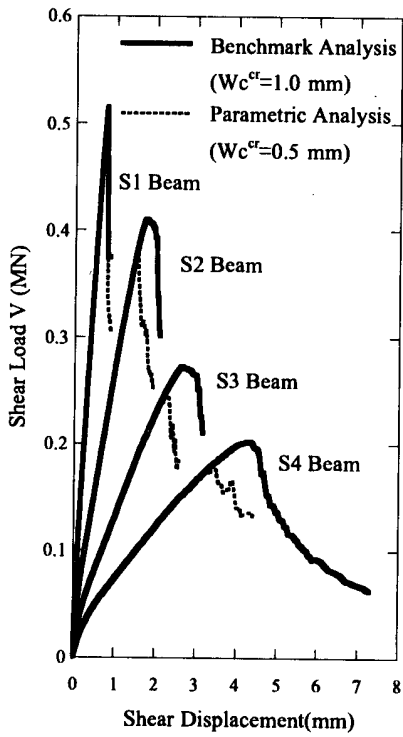

(d)

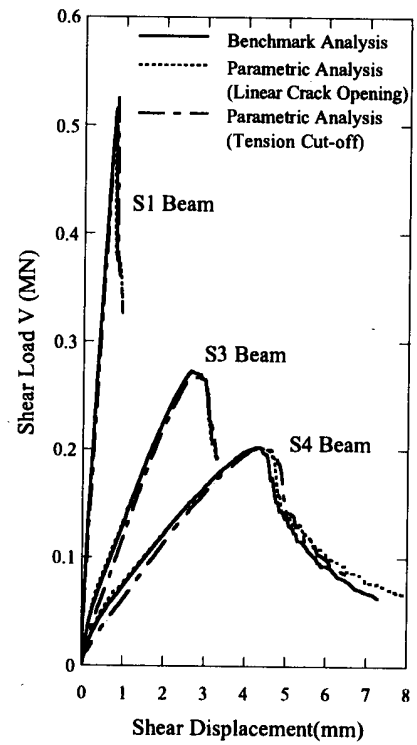

FIG. 8: Comparison of Shear Load-Displacement Relations (a) between Experiment and Benchmark Analysis; (b) in terms of Maximum Strength Reduction Rate $c$; (c) in terms of Limit Displacement $w_{c}^{\text {cr; }}$ (d) in terms of Tension Softening Models 
caused by the fact that in the case of $a / d=0.5$, the abrupt load drop after the peak load is associated with the crushed concrete zone along the shear plane, which rapidly distributed. The stress redistribution is therefore not allowed. In the case of $a / d=1.0$ or higher, the large limit displacement $w_{c}{ }^{c}$ allows the stress to be redistributed, resulting in the increase of the peak load. Thus, the post-peak ductility in the compressive constitutive model allows the increase of the load-carrying capability of concrete beams in the case of $a / d=1.0$ or higher. Based on this observation, another aspect on the effect of fiber reinforcement in concrete structures can be identified, which may be significant in the material development. This is because so far the ductility improvement of fiber reinforcement in both tension and compression is mainly recognized.

\subsection{Influence of Softening Parameters in Tension}

The sensitivity of the results from the numerical simulation to the tension-softening model was examined. In this parametric analysis, the linear crack opening model and the tension cut-off model $\left(G_{F}=0.0\right)$ are employed.

Fig. 8d shows the comparison between the results of shear loaddisplacement relations in the benchmark analysis and in the parametric analysis with the different crack opening models. In this parametric analysis, the quantities of the maximum strength reduction rate $c$ and the limit displacement $w_{c}^{c r}$ are identical to those in the benchmark analysis. There is no obvious difference of the predicted failure modes between the parametric analysis and the benchmark analysis with respect to cracking behavior. The influence of the tensile constitutive model on the numerical results in the case of $a / d=2.0$ is relatively higher than that in the case of $a / d=0.5$. There is no significant difference in the numerical results between the linear crack opening model and the exponential crack opening model. However, in the parametric analysis with the tension cut-off model, the load-carrying capability was partially lost at the early load level in the case of $a / d=1.5$ or higher. Thus, the predicted shear loaddisplacement relation is not sensitive to the shape of tension-softening model. However, in comparison with no sensitivity to the shape of tension-softening model, the consideration of the tension-softening behavior influences slightly the load-displacement relations as well as the peak load

\section{ANALYSIS FOR SLENDER BEAMS}

In the previous analysis, the sensitivity of numerical simulations to the softening parameters in constitutive models was examined based on the experimental observations in the deep beam tests. To expand the comprehension on the effect of softening parameters in the deep beams to slender beams, the beams in the shear-span ratio of 4.0 were numerically simulated. Two models were considered to examine the different failure modes (see Table 2). One is Slender Beam 1, which is identical to S4 beam except for the shear-span ratio. The other is Slender Beam 2, which is identical to Slender Beam 1 except for the reduced ratio of main steel bar $\left(p_{w}=0.744 \%\right)$. Slender Beam 2 is expected to have a flexural failure, while Slender Beam 1 a shear failure.
TABLE 2: Parameters in Benchmark Analysis for Slender Beams

\begin{tabular}{|c|c|c|c|c|c|c|c|c|c|}
\hline & $\begin{array}{c}a \\
(\mathrm{~cm})\end{array}$ & $a / d$ & $\begin{array}{c}l \\
(\mathrm{~cm})\end{array}$ & $\begin{array}{c}L \\
(\mathrm{~cm})\end{array}$ & $\begin{array}{c}p_{w} \\
(\%)\end{array}$ & $\begin{array}{c}p_{r} \\
(\%)\end{array}$ & $\begin{array}{c}f_{c}^{\prime} \\
(\mathrm{MPa})\end{array}$ & $c$ & $\begin{array}{c}w_{c}{ }^{c} \\
(\mathrm{~mm})\end{array}$ \\
\hline Beam 1 & 128.0 & 4.0 & 270.0 & 310.0 & 3.72 & 0.45 & 54.43 & 1.0 & 1.0 \\
\hline Beam 2 & 128.0 & 4.0 & 270.0 & 310.0 & 0.744 & 0.45 & 54.43 & 1.0 & 1.0 \\
\hline
\end{tabular}

\subsection{Benchmark Analysis for Slender Beams}

In the benchmark analysis for the slender beams, an exponential crack opening model, the maximum strength reduction rate $c=1.0$ (no strength reduction), and the limit displacement $w_{c}{ }^{c}=1.0 \mathrm{~mm}$ were adopted (see Table 2). The cracking patterns at the peak load for both slender beams are shown in Figs. 9a and 9b. Flexural cracks initiate at the bottom of the beam and propagate to the mid-depth of the beam in both beams. In the case of Slender Beam 1, subsequently diagonal cracks initiate at the web concrete and continue to propagate in a diagonal direction, growing excessively wide. At the load level close to the peak, the compression failure is observed at the extreme compressive fiber and the both the main reinforcement and the transverse reinforcement are yielded. In the case of Slender Beam 2, neither obvious diagonal crack nor compression failure is observed, resulting in the propagation of the flexural cracks to the upperdepth of the beam. The failure load is associated with the yield of the main reinforcement, and the transverse reinforcement is not yielded at this stage.

\subsection{Influence of Softening Parameters in Compression}

The sensitivity of the results from the numerical simulation to each of the maximum strength reduction rate $c$ and the limit displacement $w_{c}^{c r}$ was examined. Fig. 9c shows the comparison between the results of shear load-displacement relations in the benchmark analysis and in the parametric analysis with $c=0.0$ and $w_{c}^{c r}=1.0 \mathrm{~mm}$, or $c=1.0$ and $w_{c}{ }_{c}^{c r}=0.5 \mathrm{~mm}$. In this parametric analysis, the tensile constitutive model is identical to that in the benchmark analysis. There is no obvious difference in the predicted failure modes between the parametric analysis and the benchmark analysis with respect to cracking behavior. Particularly, the condition of $c=0.0$ does not give the crushing behavior at the web concrete for Slender Beam 1. As shown in the figure, the numerical results are sensitive to the value of $w_{c}^{c r}$ in Slender Beam 1 as observed in the deep beams. However, the numerical results are not sensitive to the value of $c$. It may be explained by the fact that the peak load in Slender Beam 1 with $c=0.0$ is associated with the compression failure without diagonal crack in the element at the extreme compressive fiber of the beam, and no crushing at the web concrete is observed. Therefore, the maximum strength reduction rate $c$ does not influence the compression strength. On the other hand, in Slender Beam 2, the numerical results are sensitive to the value of neither $c$ nor $w_{c}^{c r}$. Thus, the comprehension on the effect of compressive softening parameters in the deep beams can be also applied to the slender beams, if the shear failure mode is dominant and governed by the crushing at the web concrete. However, there is little effect of compressive softening parameters for the beams when the flexural failure mode is dominant. 
(a)

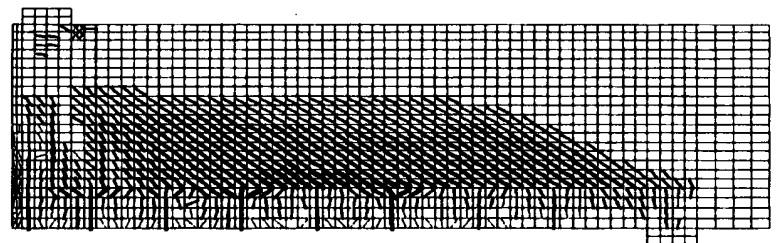

(b)

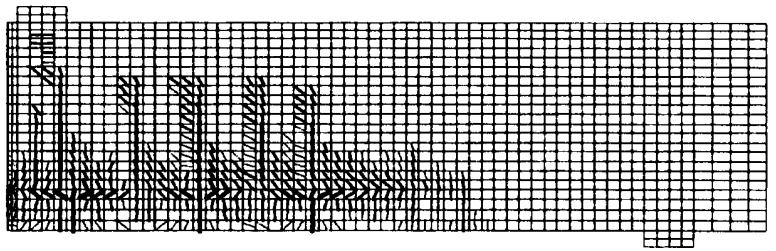

(c)

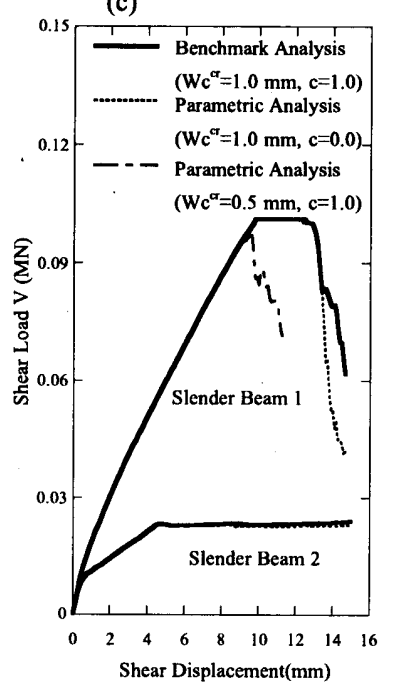

(d)

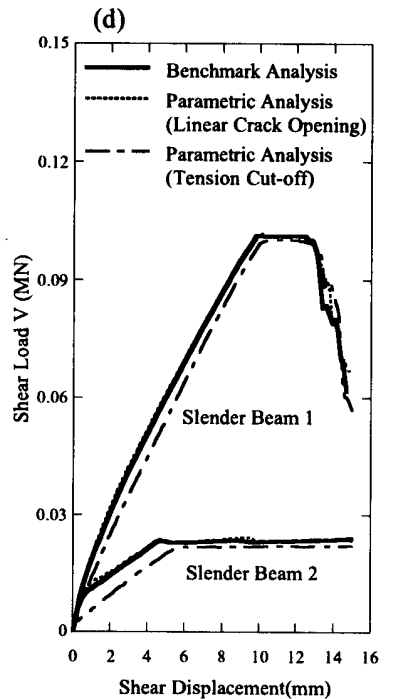

FIG. 9: Cracking Patterns at Peak Load for (a) Slender Beam 1;

(b) Slender Beam 2; and Comparison in terms of (c) Compressive Softening Parameters $c$ and $w_{c}^{c r}$; (d) Tension Softening Models

\subsection{Influence of Softening Parameters in Tension}

The sensitivity of the results from the numerical simulation to the tension-softening model was examined. In this parametric analysis, the linear crack opening model and the tension cut-off model $\left(G_{F}=0.0\right)$ are employed. Fig. 9d shows the comparison between the results of shear load-displacement relations in the benchmark analysis and in the parametric analysis with the different crack opening models. In this parametric analysis, the values of the maximum strength reduction rate $c$ and the limit displacement $w_{c}^{c r}$ are identical to those in the benchmark analysis. There is no obvious difference in the predicted failure modes between the parametric analysis and the benchmark analysis with respect to cracking behavior. As shown in the figure, the predicted shear load-displacement relation is not sensitive to the shape of tension-softening model. However, the consideration of the tension-softening behavior highly influences the numerical results in both beams, especially the significant influence in Slender Beam 2. Thus, comprehension on the effect of tension softening parameters in deep beams can be also applied to the slender beams, especially when the flexural failure mode is dominant.

\section{CONCLUSIONS}

In this paper, numerical simulations were carried out to examine the performance of constitutive models for describing the cracking behavior and the load-displacement characteristics of shear failure of reinforced concrete simple beams. Based on the structural analysis for the shear-span ratio of 0.5 to 4.0 , the following conclusions can be drawn.

The compressive strength reduction rate after cracking considerably influences the prediction of shear failure of concrete simple beams. Particularly, a large compressive strength reduction rate is necessary to approximate the shear behavior of the beams with a small shear-span ratio.

The compression-softening curve does not influence the entire loaddisplacement relation and neither the peak load in the case of small shearspan ratio $(a / d=0.5)$. However, in the case of large shear-span ratio ( $a / d=1.0$ or higher), the post-peak ductility in the compressive constitutive law allows the increase of the shear load-carrying capability of beams when the shear failure mode is dominant. Therefore, the methodology such as fiber reinforcement to increase the compressive post-peak ductility may become significant in the material development.

The shape of tension-softening model does not significantly differentiate the predicted shear load-displacement relation. However, the consideration of the tension-softening behavior highly influences the loaddisplacement relation as well as the peak load, especially when the flexural failure mode is dominant.

In the present numerical study, a particular numerical approach and particular constitutive models are employed. However, the above mentioned conclusions are qualitatively applicable to the practical analysis and also significant in the material research field.

\section{ACKNOWLEDGEMENT}

Authors would like to thank Prof. Niwa at Tokyo Institute of Technology for his kind offer of his experimental data.

REFERENCES

1) Hordijk, D.A., Mier, J.G.M. van and Reinhardt, H.W. (1989). "Material Properties, in Fracture Mechanics of Concrete Structures: from theory to applications, (ed. L. Elfgren), CHAPMAN AND HALL, pp.67-127.

2) Hillerborg, A. and Rots, J. (1989). "Crack Concepts and Numerical Modelling, in Fracture Mechanics of Concrete Structures: from theory to applications, (ed. L. Elfgren), CHAPMAN AND HALL, pp. 128-146.

3) Rots, J. G. and Blaauwendraad, J. (1989). "Crack Models for Concrete: Discrete or Smeared? Fixed, Multi-directional or Rotating?," HERON, Vol. 34, No. 1.

4) Niwa, J. (1983). "Shear Failure Mechanism of Reinforced Concrete Deep Beam," Doctoral Dissertation, Tokyo University.

5) SBETA (1997). "SBETA Computer program for nonlinear finite element analysis of reinforced concrete structures in plane stress state," Program documentation, Cervenka Consulting, Prague.

6) Kupfer, H., Hilsdorf, H.K., Rusch, H. (1969). "Behavior of Concrete under Biaxial Stress," ACI Journal, V.66,No.8, Aug., pp.656-666.

7) Chen, WF, Saleeb, AF. (1982). "Constitutive Equations for Engineering Materials," John Willey \& Sons.

8) Kollegger, J. - Mehlhorn, G. (1988). "Experimentelle und Analytische Untersuchungen zur Aufstellung eines Materialmodels fuer Gerissene Stahbetonscheiben," Nr.6 Forschungsbericht, Massivbau, Gesamthochschule Kassel.

9) Vecchio F. J. and Collins M. P. (1986). "The Modified Compression-field Theory for Reinforced Concrete Elements subjected to Shear," ACI Journal 83(2), pp. 219-231.

10) Crisfield, M.A., Wills, J. (1989). "The Analysis of Reinforced Concrete Panels Using Different Concrete Models," Jour. of Engng. Mech., ASCE, Vol. 115, No 3, March, pp.578-597.

11) Hordijk, D.A. (1991). "Local Approach to Fatigue of Concrete," Doctoral Dissertation, Delft University of Technology, The Netherlands.

12) CEB-FIP Model Code 90 (1990). First Draft, Comite Euro-Intemational du Beton, Bulletin dinformation No. 195,196, Mars.

13) Mier, J.G.M. van (1986). "Multiaxial Strain-softening of Concrete," Part I: fracture, Materials and Structures, RILEM, Vol. 19, No.111.

14) American Concrete Institute (1989). "Building Code Requirements for Reinforced Concrete," (ACI 318-89), American Concrete Inst., Detroit, Michigan.

15) Chen, W. F. (1982). "Plasticity in Reinforced Concrete," McGraw-Hill Book Company.

16) Balakrishnan, S., and Murray, D. (1988). "Concrete Constitutive Model for NLFE Analysis of Structures," Journal of Structural Engineering, ASCE, Vol.114(7). 


\section{和文要䄪}

\section{1. 序}

コンクリートのせん断破壊メカニズムは、これまでにも数多く議 論されてきたが、まだ十分には解明されていない。また、これまで にさまざまなひび割れの評価手法が提案されてきたが ${ }^{11} 、$ 複雑なコ ンクリートのせん断破罣挙動を数值解析的に十分に評価するまでに は到っていない。本研究では、回転分散ひび割れモデルを用いて、 コンクリート構造物のせん断破壊現象評価に与える構成則パラメー 夕の影響について数値解析的に検討した。異なるせん断スパン比を 持つ鉄筋コンクリート単純梁のせん断実験に対して、ひび割れ挙動 と荷重 - 変位関係を評価できる構成則パラメータを設定し、これを ベンチマーク解析とした。これに対し、構成則軟化パラメータを変 動させた時の解析結果への影響を検討した。これを、パラメトリッ ク解析とした。

\section{2. ベンチマーク解析}

\section{1 ディープビームせん断実験}

図 1 に示す既往のティープビームせん断実験 ${ }^{4}$ に対して、数值解 析を行った。表 1 に試験体の詳細を示す。実験では、せん断スパン 比が 1.0 以下の場合、試験体ウェブ部分に明確な圧壊を伴うせん断 破壊モードが観察され、せん断スパン比が 1.5 以上の場合、試験体 ウェフ部分に明確な圧壊を伴わないせん断破壊モードが観察された。

\section{2 有限要素法解析}

有限要素法解析は、Cervenka 等により開発された SBETA ${ }^{5)}$ 有 限要素法プログラムにより、回転分散ひび割れモデルを用いて行っ た。引張構成則は、ひび割れ発生前は線形弾性とし、引張軟化部分 は図 2 に示すように、指数関数軟化モテル ${ }^{111}$ 、線形軟化モテル、引 張破断モデルを用いた。圧縮構成則は、図 3 に示すようにピーク前 をパラボラ形状 ${ }^{12)}$ とし、ピーク後は線形軟化モデル ${ }^{13)}$ とし、ピーク 応力から応力が 0 となるまでの圧縮変位を限界変位 $w_{c}^{c r}$ と定義した。 また、ひび割れ発生後の要素の圧縮強度低下（図 4) は、圧絔ス卜 ラットに直交する引張ひずみの関数として式（3）により評価した。 式中の定数 $c$ は最大強度低下率を示す。

\section{3 せん断実験結果とベンチマーク解析の比較}

解析モデは、図 5 に示すように 2 分の 1 モデルとし、四角形平 面応力要素を用い上部より強制変位を与える。なお、鉄筋の応力 ひずみ関係は完全弾塑性モデルとし、主筋は四角形平面応力要素に 埋め込まれる離散線要素を用い、せん断補強筋は四角形平面応力要 素に分散させてその剛性と応力を評価した。ベンチマーク解析では、 引張軟化モデとして指数関数軟化モデルを用い、限界変位 $w_{c}^{c r}$ は $1.0 \mathrm{~mm}$ 、最大強度低下率 $c$ は図 6 に示す值を採用した。有限要素法 解析で得られた最大荷重時のひび割れ状況（図 7) は、実験で観察 されたように、せん断スパン比 1.0 以下の明確な圧壊を伴うせん断 破壊、及びせん断スパン比 1.5 以上の明確な圧壊を伴わないせん断 破壊モードをほほ再現した。図 $8 \mathrm{a}$ に実験及び解析で得られたせん 断荷重 - 変位関係を示す。図より、概水実験結果と解析值は整合し ており、ひび割れ状況も含めてベンチマーク解析は、実験結果を再 現していると考えられる。このベンチマーク解析を基本にして、次 に構成則パラメータを変えたパラメトリック解析を行った。

\section{3. パラメトリック解析}

\section{1 圧樎軟化パラメータの影慗}

図 $8 \mathrm{~b}$ にベンチマーク解析結果と最大強度低下率 $c$ を 0.0 あるい は 1.0 としたパラメトリック解析結果のせん断荷重 - 変位関係の比 較を示す。図より、せん断スパン比が 0.5 の場合、極端な違いが見 られるが、せん断スパン比が大きくなるとこの差は減少する。せん 断スパン比が 0.5 の梁では、 $c$ が 1.0 の場合、破壊モードがウェブ 部分の明確な圧罗を伴うせん断破壊ではなく、支持点近傍のコンク リートの支压破壊となった。逆にせん断スパン比が 1.5 以上の梁で は、 $c$ が 0.0 の場合、破壊モードがウェブ部分の明確な圧壊を伴う
せん断破壊となった。このように解析で得られた破壊モード及びせ 儿断荷重 - 変位関係は最大強度低下率 $c$ の影響を強く受ける。

図 $8 \mathrm{c}$ にベンチマーク解析結果と限界変位 $\mathrm{w}_{c}^{c r}$ を $0.5 \mathrm{~mm}$ とした パラメトリック解析結果のせん断荷重 - 変位関係の比較を示す。破 壊モードには㩆著な差は見られなかったが、せん断スパン比が 1.0 以上の梁は、限界変位 $w_{c}^{c r}$ が大きいほど、最大荷重も増加する傾向 を示した。

\section{2 引張瑱化パラメータの影檕}

図 8d にベンチマーク解析結果と、引張軟化モデルを線形軟化モ デル及び引張破断モデルとしたパラメトリック解析結果のせん断荷 重 - 変位関係の比較を示す。破壊モードには顕著な差は見られなか ったが、全般的にせん断スパン比が大きい梁ほど大きい差を示した。 線形軟化モデルと指数関数軟化モデルによる引張軟化モデルの形状 差がせん断荷重 - 変位関係に与える影響はほとんどないが、引張軟 化挙動の考慮の有無が与える影響は見られた。

\section{4. 細長い梁の解析}

\section{1 ベンチマーク解析}

ティープビームせん断実験に対する数值解析により得られた知見 を細長い梁に拡張するため、せん断スパン比 4.0 の梁を解析した。 モデルは 2 種類（表 2）とし、一つはせん断破壊モードが卓越し、 他方は主筋を少なくして曲げ破壊モードが卓越するものとした（図 $9 \mathrm{a}, 9 \mathrm{~b})$.

\section{2 圧縮軟化パラメータの影皙}

図 $9 \mathrm{c}$ にベンチマーク解析結果と、 $\left(c=0.0 、 W_{c}^{c r}=1.0 \mathrm{~mm}\right)$ とし た場合及び ( $\left.c=1.0 、 W_{c}{ }^{c r}=0.5 \mathrm{~mm}\right)$ とした場合のパラメトリック解 析結果のせん断荷重 - 変位関係の比較を示す。破壊モードには顕著 な差は見られなかった。せん断破壊モードが卓越する梁では、 $w_{c}^{c r}$ の影響が見られたが、c の影響は見られなかった。これは、梁上縁 の圧縮破壊要素にひび割れが含まれていないことに起因すると考え られる。一方、曲げ破壊モードが卓越する梁では、 $w_{c}^{c r}$ 及び $c$ の影 響は見られなかった。

\section{3 引張軟化パラメータの影䇺}

図 $9 \mathrm{~d}$ にベンチマーク解析結果と、引張軟化モデルを線形軟化モ デル及び引張破断モデルとしたパラメトリック解析結果のせん断荷 重 - 変位関係の比較を示す。破壊モードには顕著な差は見られず、 線形軟化モデルと指数関数軟化モデルによる引張軟化モデルの形状 差がせん断荷重 - 変位関係に与える影響はほとんどないが、引張軟 化挙動の考慮の有無が与える影響は大きい。特に、曲げ破壊モード が卓越する梁では大きな差が見られた。

\section{5. 結論}

本研究では、コンクリート構造のせん断破壊におけるひび割れ挙 動及び全荷重一変位特性を数值解析的に評価するための構成則パラ メータの影響を検討した。0.5 から 4.0 までの異なるせん断スパン 比を持つ鉄筋コンクリート単純梁を対象に、回転分散ひび割れモデ ルを用いた非線形有限要素法によりパラメトリックな構造解析を行 い、以下の知見を得た。

コンクリート要素ひび割れ後の圧縮強度低下率が与える数值解析 結果への影響は大きく、特にせん断スパン比が小さい梁に対しては 大きな圧縮強度低下率が必要である。

圧縮構成則のポストピーク軟化勒性パラメータが与える数值解析 結果への影響は大きく、せん断スパン比が 1.0 以上のせん断破壊モ 一ドが卓越する梁に対しては、大きな勒性值ほど大きな最大荷重を 与える。このことより、織維補強などの引張及び圧縮鞋性值を増加 させる手法は、材料開発において意義をもつと考えられる。

引張軟化モデルの形状差がせん断荷重 - 変位関係に与える影響は 小さいが、引張軟化举動の考慮の有無が与える影響は大きく、特に 曲げ破壊モードが卓越する梁では顕著となる。 